\title{
The franchise relationship in China: Agency and institutional theory perspectives
}

\section{Introduction}

The number of franchise outlets in China is estimated to grow to 800,000 by 2016 , creating more than 10 million jobs (China Daily, 2011). These figures rival current US statistics where franchising accounts for more than $50 \%$ of retail and service revenue and $14 \%$ of private sector employment (Franchiseek, 2011). Franchising in China is a relatively new phenomenon (Wang, Zhu and Terry, 2008); the franchise relationship, and the resulting constructs of power, control, support and conflict, remain under-researched.

Franchising theory has been developed in the context of franchise systems operating in market economies with established institutional structures (Dant, 2008; Holmberg and Morgan, 2003; Kedia et al., 1994; Meek et al., 2011). The economic perspective provided by agency theory (Jensen and Meckling, 1976) dominates the literature (Barthelemy, 2008; Castrogiovanni et al., 2006a, 2006b; Combs et al., 2004a). A sociological viewpoint such as that provided by institutional theory has the potential to explain elements of the franchise relationship which the economic perspective alone overlooks (Shane and Foo, 1999; Combs et al. 2009; Barthelemy, 2011).

In this paper we seek to discover aspects of franchise relationships in China that are not fully reflected in current theoretical understanding. By employing both economic and sociological approaches we provide a holistic understanding of the franchising relationship in a dynamic, developing economy. By providing evidence from both franchisors and franchisees we offer a more robust view of the franchise relationship. This contributes to redressing the imbalance in extant research which is dominated by the franchisor viewpoint.

\section{The Franchise Relationship}

Grunhagen and Dorsch (2003, p.367) contend that "the franchisor-franchisee relationship represents a partnership conducted as a form of relational exchange". Relationship building 
involves sharing of benefits and costs. The formal basis of the relationship is the franchise contract. The franchisor provides the franchisee with the right to sell products or services. In business format franchising this includes use of a brand name owned by the franchisor. In return for a lump sum payment and an annual royalty fee based on sales, the franchisor gives the franchisee the right to use this intellectual property for a specified time period. The franchisee, in return for franchise fees, expects to operate in a supported and assisted environment (Fulop and Forward, 1997). Rahatullah and Raeside (2008, p.27) describe relational exchange relationships as "durable, dynamic, and adaptable", emphasizing that the relationship constructs of support, power and control, facilitate "an effective, efficient, and long-lasting dyadic relationship".

The foundational work on power by French and Raven (1959), and later work by Lusch (1976) and Gaski (1984) provide the basis for understanding power within the franchise channel. This early franchise research is US market focused, while later authors explore relational constructs in the franchise relationship in developed markets outside of the US: Australia and the UK (Quinn, 1999; Quinn and Doherty, 2000; Frazer et al., 2007; Brookes and Roper, 2011). These authors emphasize controlling the franchise relationship through non-coercive power sources, such as support mechanisms, rather than coercive sources of power, such as the contract (Quinn and Doherty, 2000; Brookes and Roper, 2011).

In international franchise relationships, communication, trust and the choice of franchise partner are important sources of power (Doherty and Alexander, 2006; Doherty, 2009). Moore et al. (2004) support Lusch (1982) in finding that cultural disconnection is a key source of conflict with international partners. They also find that channel members' willingness to exert coercive power does not encourage healthy channel relationships (Moore et al., 2004). Doherty and Alexander (2006) and Quinn (1999) assert that non-coercive power sources, particularly collaborative decision making, produce better franchise relationships.

In exploring sources of conflict, Frazer et al. (2012) highlight the tensions which emanate from expectation gaps at the outset of the relationship, distrust in the relationship, relational dissatisfaction and perceptions of conflict. However, these authors further perpetuate the focus on developed market economies with established legal and social frameworks. Detailed consideration of the dynamics within the franchise relationship in markets with emerging 
economies, evolving legal frameworks and rapidly changing social expectations remains under-researched.

\section{Theoretical Frameworks}

Agency theory (Jensen and Meckling, 1976) is based on the concept of the principal-agent relationship: the principal delegates work to the agent to be carried out on the principal's behalf on a day-to-day basis. Two agency problems arise in this context: horizontal and vertical agency (Combs et al. 2004a). The horizontal agency problem concerns the franchise brand and the potential for free riding by franchisees (Brickley and Dark, 1987; Kidwell et al., 2007). The vertical agency problem concerns the potential for employees to act self interestedly against the wishes of management (Combs et al., 2004a; Jensen and Meckling, 1976). Franchisees are not employees and will not shirk because income is directly related to effort: they are profit motivated. Employees require closer monitoring than franchisees; therefore, franchising is expected to reduce monitoring costs (Rubin, 1987). However, the potential for opportunism and moral hazard remains. On the double agency problem Combs et al. (2004a, p.912) conclude: "geographic dispersion creates two problems for chain managers. They must motivate and monitor outlet managers to solve vertical agency and they must insure that investments in the brand are maintained to solve horizontal agency."

Control, power, monitoring and the resultant potential for conflict are implicit in agency theory. A hierarchical, dependent relationship characterizes this theoretical perspective. Barthelemy (2011) concludes that agency theory alone does not fully explain how the franchise relationship operates in practice. Franchise relationships may be further explained by institutional theory, with its emphasis on the institutions and culture which shape the business environment (DiMaggio and Powell, 1983; Scott, 1995, 2008).

\section{TAKE IN TABLE I HERE}

North (1990), Di Maggio and Powell (1983) and Scott $(1995,2008)$ are the key protagonists of what is known as new institutionalism. Scott (1995, 2008), taking a sociological perspective, defines institutions as comprising "regulative, normative and cultural-cognitive elements that, together with associated activities and resources, provide stability and meaning to social life" (Scott, 2008, p.48). These regulative, normative and cultural-cognitive systems 
are known as Scott's three pillars of institutions and form the basis for legitimacy. These systems may be in conflict at any one time and are not necessary mutually reinforcing. Here it is worth quoting Scott (2008): "The regulatory emphasis is on conformity to rules: legitimate organizations are those established by and operating in accordance with relevant legal or quasi-legal requirements. A normative conception stresses a deeper, moral base for assessing legitimacy. Normative controls are more likely to be internalized than are regulative controls, and the incentives for conformity are hence likely to include intrinsic as well as extrinsic rewards. A cultural-cognitive view points to the legitimacy that comes from conforming to a common definition of the situation, frame or reference....[it] is the "deepest" level, because it rests on preconscious, taken-for-granted assumptions" (Scott, 2008, p.61).

Shane and Foo (1999) find that new franchise system survival is better explained when employing institutional explanations alongside economic reasons. In their US sample, franchise survival is more likely where there is cognitive legitimacy; that is, taken-forgrantedness derived from an established shared understanding (Shane and Foo, 1999). 'Certification by the media', that is, socio-political approval by the media in the form of published franchisor rankings, plays a key role in legitimizing franchisors. Those US states which have disclosure and termination laws help franchisors attract franchisees by protecting them against opportunistic and/or financially risky franchisors (Shane and Foo, 1999).

Combs et al. (2009, p.1270) also find that "social forces described by institutional theory add explanatory power beyond that offered by economic explanations". Barthelemy (2011) provides evidence of mimetic isomorphism, that is, franchise chains imitating the behaviour of competitors which moves the system towards a taken-for-grantedness position. Like the work of Combs et al. (2009), Barthelemy's contribution is focused on the decision to franchise and the mix of franchise and owned stores in a franchise chain. Shane and Foo (1999) and Combs et al. (2009) explore these ideas in a US context; France provides the location for Barthelemy's (2011) contribution. In both countries franchising is a long established organizational form operationalized in the context of legitimizing frameworks. However, Combs et al. (2009, p.1283) assert that "institutional theory is most relevant when uncertainty is high, relative to economic imperatives."

The developing nature of franchising in China presents a pertinent site to explore economic and social influences within the franchise relationship. Therefore, we consider the developing 
franchise relationship, rather than issues such as the decision to franchise or move to company outlets, which have dominated the franchise debate. In China, institutional mechanisms are still evolving: private enterprises were legalized in 1988 ( $\mathrm{Lu}$ and Tao, 2010). As Tan et al. (2009: 546) note "the formal, regulatory, coercive institutional mechanisms that under gird a market economy like property rights, company law and contracts, legal frameworks for managing and settling disputes, and concomitant sanctions are still evolving, or in some instances non-existent."

\section{Franchising in China}

Dant (2008) highlights the North American dominance of franchising research. The challenge of emerging economies has attracted researchers (Welsh et al., 2006), although research to date has provided very little primary data collection and analysis of how the franchise relationship in China operates. Establishing an understanding of the regulatory pillar is the first step in providing a context for the current work.

Wang et al. (2008) provide a concise historical account of how franchising has developed in China. They distinguish three stages of franchise development: stage one (1987-1992), the introduction of the franchise concept with the arrival of US fast food pioneers; stage two (1993-1997), the adoption of franchising by local enterprises; stage three (1998-2006), the rapid growth of franchising and associated problems. As franchising developed, problems arose "from a lack of understanding of franchising and the intricacies of the franchisor/franchisee relationship" (Wang et al., 2008: 172/3). Table II outlines consequent development of franchise regulation in China.

\section{TAKE IN TABLE II HERE}

With some ambiguity in the 2005 Franchise Measures, the 2007 Franchise Regulations were introduced to address a range of issues including full disclosure of information to franchisees by franchisors and the combating of fraud. The importance of support for franchisees is highlighted in the 2007 Regulations. It is seen as fundamental to the long-term development of franchising in China. Having provided this background, the paper now presents the methods employed, data collection and analysis techniques. 


\section{Methodology}

\section{Research position}

Elango and Fried (1997, p.77) advocate fine grained approaches to franchise research: "the actual operations of a franchising system have rarely been directly examined". The last decade witnessed a growth in the use of qualitative methods in retail franchising research: ethnography (Quinn, 1999), case studies (Doherty, 2009) and in-depth interviews (Moore et al., 2004). By employing in-depth interviews with franchisors and franchisees in the retail sector in China we seek to develop an understanding of franchising in a dynamic economic and social environment. Qualitative research is particularly challenging, especially with regard to company access. The access achieved is deemed to be a particular strength of the work presented here.

\section{Sample selection and securing access}

When conducting research on business activities in China it is important to establish a relationship, usually through referral, with potential respondents (Bruton and Ahlstrom, 2003). Two institutions were deemed to be central to advancing the work; the China Chain Store and Franchise Association (CCFA) and the government authority in the region where the research was carried out, the Guangdong Provincial Administration for Industry and Commerce.

The China Chain Store and Franchise Association (CCFA) provides a range of information and services on retailing generally, and franchising specifically. It deems itself to be the official representative of the retailing and franchising industry in China, with a membership that includes domestic retailers, international retailers, franchisors, suppliers and other related organizations (CCFA, 2011). The CCFA membership database provided the best opportunity for identifying those retail franchise organizations which would fit with the case selection criteria:

Selection Criterion 1: Operate in China in the retail sector via franchising 
Selection Criterion 2: Operate within a confined geographical area in order to minimize variation from external influences. The area of the Pearl River Delta was chosen for the current work

Selection Criterion 3: Have experience of at least one year franchising in the retail sector in China. Both international and domestic retailers were eligible.

The CCFA has many divisions operating on a provincial basis in China and CCFA Guangdong represents the CCFA in this province. Guangdong Provincial Administration for Industry and Commerce is the key governmental department mainly responsible for regulating the circulation of goods, investigating and enforcing any trade mark infringements with responsibility for all trademark management for all industrial and commercial enterprises. In the chain store and franchise industry, the department works closely with the CCFA to regulate the franchise companies in the area of Guangdong province.

Initial contact was made with the CCFA and Guangdong Provincial Administration for Industry and Commerce. Via personal contacts, two CCFA Guangdong consultants were already known to the research team. While both contacts had been working closely with the member companies of CCFA in Guangdong province, they could not directly access companies without the authorisation of the higher administration of CCFA Guangdong. In order to approach the higher administration, it was advised that it was necessary to seek support from the government. The government department was initially approached through a different personal contact. Once senior officers understood the nature of the research project and offered their consent for support, the two CCFA Guangdong consultants were then authorised to help make initial contacts with target companies.

Using the CCFA database twenty-five retail franchisors were found to fit with the preceding criteria and were contacted via telephone to explain the purpose of the research and request interviews with key personnel. Five companies refused to participate in academic research due to concerns over the protection of sensitive commercial information. No response was received from two organizations leaving eighteen retail franchisors. Following initial phone calls to the franchisors by the CCFA consultants, phone calls were then made by one of the researchers to specific personnel to confirm the time, venue and form of the interviews. Following this process twelve franchisors gave their final agreement to participate in the research. 
Franchisee access was secured via franchisors. Some franchisees were reluctant to participate in interviews, therefore it was not possible to secure access with both franchisors and franchisees in all twelve companies. As the work focuses on the franchise relationship, only the nine retail franchise organizations where access to both franchisors and franchisees was secured are included in this paper. Given the nature of doing research in China it was deemed appropriate to secure access to firms at the outset, but during the course of the research a consistent picture of the franchise relationship in China began to develop, reflecting a replication logic as advanced by Eisenhardt (1989). Details of the nine retail franchise organizations are provided in Table III.

\section{TAKE IN TABLE III HERE}

\section{Data collection and data analysis}

The broad research objective is to identify the central tenets of the franchise relationship in China. The setting of this objective follows the guidance of Eisenhardt (1989) on the collection of qualitative data. Table IV highlights the key thematic issues explored in both franchisor and franchisee interviews. To ensure consistency of structure during the course of interviewing, interviews were guided by an inventory of issues tightly pertaining to the research objective. As the interviews progressed, further questions and prompts followed when there were additional and complementary issues raised by respondents.

\section{TAKE IN TABLE IV}

Interviews were held in Chinese and detailed hand written notes were also taken. Interviews were tape-recorded upon the consent of the informants and each interview was transcribed in Chinese and carefully translated from Chinese into English. To ensure the reliability of transcription, two transcribers who are indigenous mainland China nationals with business studies qualifications carried out the task of transcribing the interviews. The transcribers were instructed to independently translate the tape-recorded content of each interview word-byword using exactly the same wording as originally used by respondents. Transcripts were compared and when there were differences the original interview tape was listened to again and the hand written notes were double checked. This procedure continued until full 
agreement was reached. In order to ensure confidentiality, companies were coded A to I and their names replaced in the transcript.

The final transcript was then translated into English. To ensure that the translation was precise and closely adhered to the original Chinese wording, five independent translators were instructed to carry out the task. They were all doctoral level Chinese native speakers and had been residents in the UK for more than three years. To ensure the consistency of specialised terms in translation, translators were provided with a reference that stipulated the Chinese and the corresponding English, such as “特許行銷” for “franchising”, “物流系統” for "logistics system" and so on. The five translated transcripts were then scrutinized and compared side by side. A final version of English translation was then attained for each interview.

Following transcription interviews were analyzed using manual analytic coding by which the integrity of the data and findings were protected (Doherty and Alexander, 2004, 2006). Following Saldaña (2009), the coding process leading to the emergence of themes from the data developed in three stages: (1) Pre-coding; (2) Developing analytical coding (3) Categorizing. Pre-coding is intended to capture a sense of the various issues embedded in the data during the first reading of the texts (Saldaña, 2009). Pre-coding was followed by descriptive coding. Descriptive coding is given as the notation of the basic information and context of respondents (Miles and Huberman, 1994). The descriptive codes are included in Table III.

Analytical codes can be either developed in advance based on existing literature or framework, or in an ad hoc fashion, where codes are driven by immediate materials and data (Kvale and Brinkmann, 2009). To conform to the primary purpose of the study, analytical codes were developed according to emerging themes and issues from data rather than predetermined. The procedure for analytical coding followed the guidance provided by Saldaña (2009) by firstly generating preliminary codes and then achieving analytical codes. Categorizing was carried out after analytical coding. Saldaña (2013, p.9) employs Grbich's definition, noting it is a process that permits data to be "segregated, grouped, regrouped and relinked in order to consolidate meaning and explanation" (Grbich, 2007, p.21). Codes that share similar concerns, similar topics or indicate similar patterns were then organised and 
sorted into the same category. During the course of the categorizing process, themes emerged from constant cross-dyad comparison between categories and codes. Emerging themes were then compared to generate the recurring themes which were most revealing of data and pertinent to the central research question. These themes are presented in the findings section below.

\section{Findings and analysis}

\section{Franchise forms}

The type of franchising practiced by the case companies proved crucial in determining how the franchise relationship operates. In the literature, business format franchising is taken to be the accepted franchise form. This is not found to be the case in this study as two different forms of franchising are being practiced. Of the nine companies, five practice business format franchising (A, B, C, G and I) where business systems, brand and retail format are key characteristics. A, B, and C are shopping goods chains; G and I are convenience store chains. Company A is the only international franchisor. The other four are domestic franchisors. Companies, D, E, F and H, convenience store franchisors, do not employ business format franchising. They employ a franchise form focused on product supply and distribution. Business systems, characteristic of business format franchising, are absent.

\section{Motivations to enter the franchise relationship}

For the franchisor, there are five driving forces behind engagement in franchise relationships. These are: an accelerated rate of store replication and market expansion through the injection of resources from the franchisee, competitive advantage facilitated by the franchisee's embedded local knowledge and property base, the opportunity to focus on core business competencies, creation of economies of scale and, in some cases, opportunism. For franchisees, the key motivating issues are: lack of entry and withdrawal barriers, benefits derived from partner resources, saving time and effort in developing own store networks, relevance of the business to the franchisees' prior experience and strength of the brand.

Above all, both franchisors and franchisees recognize the importance of a strong brand in attracting franchisees: 
We believe that our brand is the main reason for the franchisees to come to us... a brand built on tradition and reliability, good products and loyal customers. (Company B, franchisor respondent)

\section{Power and control in the relationship}

Franchisor power. Franchisor power, and potential lack of power, is derived from a range of dimensions: the contract, the brand, possession of market information and system infrastructure. The presence of a recognised brand allows franchisors to be confident in recruiting franchisees. Franchisors operating a strong brand via business format franchising are more likely to use coercive power to control franchisees:

When franchisees get caught behaving outside the rules and regulations, warning and coercion will be given to the franchisee. (Company I, franchisor respondent)

Franchisor power is enhanced through the acquisition of market information. Where the franchisor lacks market information the firm is much more dependent on the franchisee, creating an imbalance in the relationship:

The franchisee knew that we relied on his contacts to get into the market. As a result, he thought he had the privilege to challenge or even refuse our instruction... I thought any company like us at an early stage of market entry would inevitably encounter the same situation we did. (Company $\mathrm{H}$, franchisor respondent)

Stable franchise system infrastructure strengthens franchisor power and is crucial in the development of franchise relationships. The opposite is also the case: failure in franchise system infrastructure encourages non-compliance behaviour:

We know that some franchisees purchase products from other suppliers behind our backs. Punishment and threat are definitely not the right way to eliminate their activities... What we can do is to keep learning from others and improving our systems... If you are not good enough at performing your responsibilities well, you do not have the position to enforce franchisees' compliance with instruction. (Company $\mathrm{F}$, franchise manager)

Franchisee power. A key determinant of franchisee power is information exchange between franchisees:

The company has to be aware that we franchisees would communicate with each other. If they (the company) did something bad to us, it would be soon known by all of us (the franchisees)... (Company $\mathrm{G}$, franchisee respondent)

Information exchange as a source of franchisee power deters some franchisors from organising meetings of franchisees: 
We have every reason to be proud of the arrangement of the annual meeting, because not so many franchisors can do this, because this requires a lot of confidence in the company's performance on operations and the quality of the relationship with franchisees... I know some franchisors have never organised a franchisee gathering, because they are afraid that franchisees would spread negative comments. (Company I, franchisor respondent)

Company E's experience indicates that franchisees with prior business experience are more difficult to manage. Company G suggests experienced franchisees are "too smart to control". Franchisors, particularly from the convenience store sector, prefer franchisees with no previous experience of franchising. While a franchisee possessing stores in key locations is attractive to the franchisor, a very profitable store operation is an important source of power for the franchisee, impeding franchisors from adopting a punitive approach to noncompliance.

Monitoring. Monitoring mechanisms mirror those found in previous franchise studies: the use of a regional supervisor and technological equipment. Franchisors in the convenience store sector place more emphasis on control compared with their counterparts in the shopping goods sector. The use of technological equipment as a means to control the franchisee is emphasized in this sector.

For the franchisee, monitoring is a controversial issue. A large proportion of franchisees are unhappy with the frequent change of regional supervisor, insufficient help and inefficient response of the supervisor. Furthermore, some franchisees believe that the presence of a regional supervisor indicates they are not trusted by the franchisor.

\section{Sources of conflict in the relationship}

Franchisee non-compliance. The major example of non-compliance in these franchise relationships is the unethical behaviour displayed by some franchisees who sell products not approved by the franchisor. It is particularly common in the convenience store sector. Even if franchisees do not use these unauthorised channels, they are aware of their existence. The franchisee owner in Company G says it is "too complicated" and he is unwilling to "get into trouble with the company" because he perceives that he and the company "have been getting on well". 
Company $\mathrm{H}$ provides a telling example of a franchisee deliberately ignoring the franchisor's instructions in a remote market unfamiliar to the franchisor:

I am the one who has personal connections, knowledge of the market, and helps to promote the brand into the market... I was a wholesaler in this market before I started operating a franchise business, so I knew this industry and this market very well... As a franchisee I respected their advice most of the time, but sometimes when I knew their way was not going to work in my business I would just ignore them. (Company $\mathrm{H}$, franchisee respondent)

Non-compliance also occurs when franchisees are sceptical of franchisor arrangements. This includes system improvement. Franchisees are often suspicious of new systems and unwilling to bear the cost related to the installation of new equipment and to participate in further training.

Logistical problems. Price competitiveness is the main reason convenience store franchisees purchase product from unauthorised suppliers. The franchisor CEO from Company $G$ indicates that the main impediment to offering competitive prices remains the high cost of logistics and the lack of bargaining power to negotiate a lower price with upstream product suppliers.

Franchisors' logistics capability is found to be strongly influenced by two issues: poor delivery capacity across large geographic areas and an inability to accurately estimate fluctuations in product demand. Notably, the larger, more experienced, franchisors receive fewer complaints from franchisees. The importance of the issue is succinctly expressed by one franchisee: 'All I want from [Company E] is to deliver the products on time.'

These logistical problems demonstrate a franchise system growing rapidly in geographic terms but lacking infrastructure and economies of scale. This causes dissatisfaction amongst franchisees and the potential for conflict in the system.

Counterfeit goods. Particularly important in the shopping goods sector is the presence of counterfeit goods in the marketplace. This issue is different from the behaviour discussed above, in that franchisees do not source these products for their own stores. Franchisees remain concerned that franchisors are not doing enough to protect the brand from counterfeiting. 
To protect franchisees from counterfeits, most franchisors claim that they are prepared to resort to legal action but they cannot act until they catch a counterfeiter. To counteract counterfeiting, Company A encourages customers to shop at its legitimate outlets. Company $\mathrm{B}$ emphasises that is not only the responsibility of the franchisor to act against counterfeiting:

The company has responsibility to protect its franchisees from suffering loss from piracies and counterfeits.... Franchisees should also be responsible for protecting themselves and our brand. (Company $\mathrm{B}$, franchisor respondent)

Managing non-compliance. Case company franchisors employ coercive and non-coercive sources of power to manage franchisee non-compliance. Franchise contracts stipulate a series of punitive measures that will be taken if either party breaches the contract but, in practice, franchisors seldom invoke the contract to modify franchisees' non-compliance behaviour. Franchisors prefer to employ non-coercive power, mainly through communication; however, if non-compliance continues they are prepared to employ much stronger coercion and possible contract termination.

Acknowledging that franchisees sometimes engage in non-compliance behaviour as a result of poor infrastructure and support, Companies F, G, H and I addressed non-compliance through system improvements. Company $\mathrm{G}$ equipped franchise stores with an inventory management system which helps franchisees to better manage their stock and allows the franchisor to closely monitor franchisees. To improve the monitoring system, Company $\mathrm{F}$ installed a data transmission system. Company I invested in improving their logistics infrastructure by developing a company-owned logistics centre and company-managed teams.

For the franchisor respondent in Company A, "rigidly enforcing franchisees to correct their non-compliance by threatening and fining can achieve nothing but complicate the relationship and make future communication harder". For Company $\mathrm{F}$ the balance of power lies with the franchisees that have good store locations, therefore impeding the taking of punitive action:

Franchisees that break the rules and regulations, such as selling things that are not on our approval list in the shop, change the store layout and purchase products from other suppliers without our permission, are mostly those former grocery store owners... Cancelling the franchise contract is definitely not an option... (franchisor respondent)

Support mechanisms 
Franchisors provide franchisees with a range of support mechanisms: marketing, specialized training, product improvement and development. Marketing support, as stipulated in the contract, takes the form of promotion of the brand, organization of marketing campaigns and the management of public relations. Shopping goods franchisees particularly emphasize the importance of support for product improvement and development.

\section{Legal requirements and their impact on the franchise relationship}

Estimations of ROI. As required by legislation, franchisors provide estimations of franchisees potential investment returns at the pre-contractual stage. The aim of estimating return on investment is to help set franchisee expectations at a realistic level from the outset. Business format franchisors prove to be more conservative in estimating return on investment. Over exaggerating return on investment will increase franchisees expectations and has the potential to cause conflict in the relationship when they are not met.

Secure opt-out system. The second legal requirement is the secure opt-out system whereby franchisors provide a simple secure opt-out system when the franchisee wants to withdraw from the existing franchise business. Before the contract set up stage, franchisors receive frequent enquiries from prospective franchisees regarding withdrawal procedures. Since most franchisees are new to franchising, and risk averse, they require financial reassurance. The simple and safe opt-out system is more likely to enhance franchisees confidence in the venture and attract more franchisees.

\section{Social factors}

Development of emotional bonding is important within franchise relationships. The franchisor garners franchisee support by organizing periodic gatherings for immigrant franchisees new to a particular city. Some franchisors hold outdoor activities for their franchisees to meet company staff. For the franchisor, these activities enhance franchisee sense of belonging to the company. Franchisors consider that the relationship between the franchisor and the franchisee is not a purely financial one. The development of emotional bonds facilitates problem solving at the social level through negotiation and communication.

Franchisees welcome these trust building periodic gatherings. It allows them to build a muchneeded sense of belonging to their new home town. The time franchisees spend with franchisor representatives is a source of emotional affiliation which pre-empts conflict: 
The supervisor is quite nice. She is a woman of my age. We feel like a friend to each other. As a result I dare not say anything about my opinions to her... I do not want to destroy the relationship with the company... (Company I, franchisee respondent)

This time spent together engenders tolerance and comprehension, as highlighted by the franchisee from Company I:

Although dissatisfaction and misunderstandings happen sometimes, I emotionally feel closer to the company, as we get to know each other more. (Company I, franchisee)

The longer the relationship the more likely it is that the franchisee will build an emotional attachment to the franchisor. This is more prevalent in the business format franchising context because these franchisors have a longer term vision and will put a greater effort into promoting the franchisee's sense of belonging to the company.

\section{Discussion}

\section{TAKE IN TABLE V HERE}

Table V details the main sources of power, control, support, and conflict in the franchise relationship in China, from the perspective of both franchisors and franchisees. While the sources of power and control for franchisors largely conform to established understanding, that is, control through the contract, brand, support and so on (Doherty and Alexander, 2006; Frazer et al., 2007; Lusch, 1976), it is the franchisee sources of power and control which exhibit fundamentally different characteristics. Those franchisees which possess important locations for their retail outlets are able to exert significant power and control in the relationship, resulting in franchisors not wishing to exert contractual power. Support services offered to franchisees, such as marketing, training and monitoring have also been explored in previous studies (Doherty, 2007; McIntyre, 1996; Quinn, 1999). It is support via prior disclosure and the secure opt-out system which provides important insights, as these are support issues which the franchisor must provide to franchisees following the implementation of franchise legislation in China. Franchisees in this study derive extra confidence and reassurance from the legally required support mechanisms when making the decision to enter into a franchise relationship.

Sources of conflict in the franchise relationship serve to highlight the rapidly evolving nature of franchising in China. Convenience store franchisees, regardless of the type of franchising 
being operated, are likely to cause conflict in the franchise system by purchasing product from unauthorised sources, acting against franchisor recommendations by using the market knowledge they possess as a result of previous experience in retailing and being unwilling to bear the costs of improving systems. Convenience store franchisors acknowledge that in many cases such franchisee behaviour is a result of underdeveloped franchise system infrastructure. For the shopping goods sector, the presence of counterfeit goods in the marketplace causes conflict as franchisees feel that the franchisor should be doing more to combat the problem. Franchisors acknowledge they have very limited ability to deal with the issue. The prior disclosure and estimation of return process and the secure opt out or 'cooling off' period embedded in the franchise contract mitigate against the type of conflict evident in the recent work of Frazer et al. (2012) which resulted from an expectation gap at the outset of the relationship. Likewise, conflict is mitigated through the various social events franchisors organise for franchisees and the building of relationships with the regional supervisor.

Theoretically, horizontal agency problems in the form of free riding (Combs et al., 2004a; Kidwell et al., 2007) do not emerge as a problem within these franchise relationships: even within the business format franchise systems where it is most likely to occur due to the presence of strong brands. The franchise brand was highlighted as being very important in the initial decision to franchise for both business format franchisors and franchisees. Free riding infers a franchise system which is centered on a well established brand. It may be the case that these franchise systems are still developing, therefore brand strength is also evolving. However, what is witnessed in the franchise market in China is free riding occurring outside the franchise system in the form of counterfeiting. Using agency theory, free riding is viewed as an internal concept within the franchise system. The developing institutional context in China provides a view of free riding which is external to the franchise system but which has a positive effect within the system. In effect, the presence of counterfeiting outside the franchise system may well act as a barrier to free riding within it. This leads to the first proposition:

\section{P1: In a developing institutional environment which offers limited brand protection, free riding outside a franchise system will mitigate against the occurrence of free riding within the system}

By employing institutional theory we can explain aspects of the franchise relationship which lie outside the explanatory power of agency theory. While institutional frameworks are characterised by their dynamic and evolving nature, this is particularly so in an environment 
which witnessed its first piece of franchise legislation as recently as 1997. This legal framework continues to evolve, and the contract, which underpins other theories of franchising, is at an earlier level of development and maturity in China compared with other institutionally developed franchise contexts such as the UK, US and Australia where much previous research has been located (Shane and Foo, 1999; Brookes and Roper, 2011; Meek et al., 2011; Frazer et al., 2012). It is also within this developing institutional framework that counterfeiting thrives and franchisors have very limited recourse. The latter is a particular issue for the shopping goods franchisors which rely on their brand and the quality of their products to develop their franchise networks. The normative pillar (Scott, 2008) suggests behaviour is constrained by values and norms: transgression produces shame or disgrace. In China, a developing institutional context, the widespread existence of counterfeiting is a relatively accepted 'norm' in society. Counterfeiting is taken for granted behaviour, from which the developing franchise system needs protection. However, with a regulatory pillar in its relatively early stage of development, protecting franchisors and franchisees against counterfeiting remains a particular challenge. Further, there is a taken for grantedness which helps to explain convenience store franchisees buying product from unauthorised sources. As with counterfeiting, only when the regulative pillar is further established, and the 'norm' in the system means franchisees understand that they must abide by the legal requirements of the franchise contract, will this cultural cognitive norm reverse. Following North (1990), the political structure must provide the foundation for the enforcement of the contract. In some way, the cognitive legitimacy evident in the work of Shane and Foo (1999) is reversed in China, that is, the long standing shared understanding in China allows for counterfeiting and purchasing of product from unauthorised sources. This leads to the second proposition:

P2: In a developing institutional context, where cultural cognitive norms have the potential to undermine the power of franchise contracts, a stronger regulatory pillar will overcome deviant taken for grantedness behaviour

While evidence of horizontal agency does not emerge from the findings, agency theory is shown to have explanatory power when viewed in terms of the vertical agency problem. Opportunism and moral hazard are prevalent within these franchise relationships, particularly within the convenience store sector. There are numerous examples of franchisees operating opportunistically by purchasing product from suppliers other than the franchisor. According to agency theory, power resides in the franchise contract and by inference the franchisor is more powerful that the franchisee (Combs et al., 2004a; Jensen and Meckling, 1976; Mathewson and Winter, 1985). However, in China, when franchisees possess prime 
locations, franchisors are largely unwilling to invoke the contract punitively. This is a particular problem where franchisees derive market knowledge from previous experience within the retail sector. This leads to the following propositions:

\section{P3: Vertical agency problems are more likely to arise when franchisees possess previous retail experience and prime retail locations}

P4: The lack of a developed regulatory institutional environment results in the potential for vertical agency problems

Within a rapidly evolving franchise network some franchisors admit that their infrastructure is not sufficiently developed, particularly in terms of logistics and replenishment, which makes contract enforcement difficult. Convenience store franchisees are particularly price driven. When they think they are not receiving sufficiently competitive prices from their franchisor there is a greater likelihood that they will source from other channels. Franchisors have recourse to the contract but they acknowledge that sometimes it is the limitations of their systems which instigate franchisees non-compliance. This leads to the fifth proposition:

P5: Vertical agency problems will occur in a rapidly evolving franchise market when franchisors lack sufficient franchise network infrastructure

In order to attempt to minimize vertical agency, monitoring occurs via the regional supervisor and technological equipment. Convenience goods retailers monitor via information systems to ensure franchisees are adhering to their contract and not sourcing product from unauthorized channels. Many convenience store franchisors monitor with limited success. Shopping goods retailers, with their emphasis on the brand and business format franchising, do not exhibit the same vertical agency issues; therefore, franchise form and retail sector are important in this regard. Convenience store franchisees are more likely to behave opportunistically and therefore cause conflict in the system. The franchise relationships in this sector tend to operate at the discreet transactional end of the relationship continuum. In contrast, shopping goods business format franchisors operate in a context where the longer term relationship is more important than the individual transactions which occur (Kaufmann and Stern, 1988). Evidence from the business format franchisors in the current work supports Spinelli and Birley's (1996) contention that support is central to relationship development and tolerance. This leads to propositions six and seven:

P6: Agency problems are contingent on franchise form and retail sector

P7: Transactional franchise relationships are more likely to lead to conflict in the franchise system 
Following Giddens' (1984), DiMaggio (1991) emphasizes the importance institutional theory places on government agencies and trade associations (DiMaggio and Powell, 1983). These agencies and associations are crucial to the definition of an industry and the emergence of networks, both formal and informal which support, police and/or set policy with regard to the industry. The data collection phase highlighted this defining process within the franchise industry in China. The CCFA and government agencies give a legitimization to franchising in the country and as such provide a key basis for understanding institutional development. This leads to the eighth proposition:

P8: Defining the franchise industry in a developing institutional environment leads to legitimacy and provides a basis for institution building within this context

The implementation of key elements of the legal framework noted in Table One (Franchise Measures 2005 and Franchise Regulations 2007) is highlighted in the findings. Franchisors' prior disclosure of return on investment estimations and the secure opt out or 'cooling off' period are all evidenced here. Their importance in giving franchisees confidence at the outset of the relationship cannot be underestimated. This echoes the work of Shane and Foo (1999) who find that disclosure laws encourage potential franchisees into the franchise system, with regulation providing important legitimacy for the industry. The Franchise Regulations 2007 note that franchisors must provide support to franchisees, but the legislation is quite general in terms of support expectation. Findings reveal a range of support mechanisms in operation within the case firms. Therefore, while the evolving nature of the institutional environment is acknowledged, the legislation which does exist is being implemented.

The nature and importance of personal connections and information exchange also emerge as important cultural-cognitive dimensions of the franchise relationship, as are the social factors emphasised by both franchisors and franchisees. When franchisees begin to develop closer personal bonds with their regional supervisor they begin to feel closer to the company as a whole. Periodic gatherings organised by franchisors help to build trust with franchisees. Many franchisees have moved from the countryside to the cities, therefore such gatherings and involvement with the franchise system provide a sense of belonging. Further, information exchange between franchisees acts as a source of power for them. On a negative note, those franchisees with previous retail experience also draw on their personal networks to procure product from outside the franchise system. This leads to the penultimate proposition:

P9: Personal connectivity present in the franchise relationship moderates culturalcognitive dimensions within the institutional environment 
Combs et al. (2009) emphasise the pressure to conform inherent in institutional theory which bring isomorphic pressures to bear on firms within the same industry. If we take the two retail sectors considered here, we can see evidence of isomorphic pressures. The convenience store sector is more concerned with price and its implications whereas the shopping goods sector is more concerned with brand and product quality. This leads to the final proposition:

\section{P10: In a developing institutional environment, isomorphic pressures present themselves at the retail sectoral level rather than the industry level}

Combs et al. (2009) acknowledge that their study only explored institutional theory's explanatory power for firms' propensity to franchise. The current work explores the franchise relationship holistically and therefore offers a further extension of their work in terms of the role institutional theory can play in our understanding of the ongoing franchising relationship outside the traditional economic perspectives which have dominated the literature for more than four decades.

\section{Implications for franchising practice}

Franchisors and franchisees already operating or considering entering into a franchise relationship in China must be aware that while franchising as an organizational form is growing, it is still at an early level of development. Franchising legislation does exist and it requires franchisors to provide support to franchisees, as well as financial reassurances which come from prior disclosure and the secure opt-out system. These issues encouraged franchisees in the current study to enter into the franchise system. That said, the institutional framework remains relatively weak and contract enforcement is difficult, particularly in the convenience store sector for those firms not practicing business format franchising. Franchisors would be advised to build and develop strong brands which would allow them to develop a business franchise format. This attracts franchisees that understand the power of the brand and are therefore less likely to act outside the system. Without a strong brand, many convenience store franchisors are simply employing franchising to distribute product and are reliant on a distribution system without strong infrastructure. This weakens their position visa-vis franchisees in a highly competitive, price-driven market place. 
Across sectors and franchise forms, support mechanisms help to develop the franchise relationship. Investment in these support mechanisms is crucial for long-term success. Franchisors should be aware of the important role the regional supervisor plays in maintaining stability in the relationship and reducing the potential for conflict in the system. Potential franchisees would be advised to explore the support mechanisms a prospective franchisor purports to provide. Only prior disclosure and the secure opt-out system are specifically detailed in the legislation.

\section{Conclusion, limitations and areas of future research}

This is an exploratory qualitative study and is therefore subject to the limitations of the method. The study is not intended to be generalizable but these data are deemed to be of value in themselves, providing thick descriptions and rich details (Cope, 2011). That only one geographic area of China is addressed could be deemed a limitation of the current work. However, the Pearl River Delta is a very developed area of China and it is a region which has been the site of previous related studies such as Bruton and Ahlstrom's (2003) work exploring the differences between western venture capitalism and that which occurs in China. Franchisee informants in the current work were secured via their franchisor. There is the potential that franchisors chose their 'best' franchisee. However, with the assurances of confidentiality we are confident respondents discussed issues honestly: that a range of conflict sources were found is testament to that. Finally, this study is focused on two sectoral groups within retailing, shopping goods and convenience stores. This was a result of the sampling procedure (Cope, 2011) and all participant companies met the criteria set for inclusion in the study.

On the basis of this work carried out in an under-researched marketplace, several areas are recommended for further study. First, much franchise research assumes business format franchising is being practiced. The current work reveals that in an emerging franchise system this cannot be assumed, as in the case of some of the convenience store franchisors in the current work. Much franchise research is characterised by theoretical positions that explain the initial decision to franchise rather than the mechanisms of the franchise relationship. The current work supports Doherty and Alexander (2004) and Meek et al. (2011) in their calls for researchers to consider the process of franchise relationship development. In the context of 
China, two areas of research could prove particularly rewarding: a longitudinal study which explores how franchise relationships develop over time within the changing institutional environment; a study which explores relationship terminations and conversion from one franchise system to another.

This paper contributes to our knowledge of franchising in numerous ways. First, it provides an account of the legislative context within which franchising in China operates. Secondly, through securing access to nine franchise networks and providing evidence from both franchisors and franchisees, the findings presented demonstrate that power, control, support and conflict are all present in the franchise relationship in China. This work supports the shared view of Shane and Foo (1999) and Combs et al. (2009) that institutional theory can provide social explanations for franchising. This is particularly relevant in an environment where the institutional framework is still evolving. However, it is also important to note the robustness of the explanatory power of agency theory (in the context of vertical agency) in a market environment outside which it is normally applied. The lack of horizontal agency in the form of free riding is particularly interesting when viewed in light of institutional weakness where brand protection is limited and where counterfeiting is endemic. A dedicated study of business format franchisors across sectors would elucidate whether free riding is not an issue generally in China and whether the endemic counterfeiting present in the market does act as a barrier to free riding in franchise systems in this developing institutional context. Moreover, an exploration of this 'external' free riding issue in the form of counterfeiting as it occurs in other developing institutional contexts outside China would further our understanding of horizontal agency issues in alternative settings to those which currently dominate the literature.

As the regulatory environment becomes more firmly established, it is important to understand how cultural cognitive norms change and how this changing institutional environment impacts on deviant taken for grantedness behaviour. In addition, an in-depth study into the social factors which moderate the franchise relationship could prove particularly insightful. A larger quantitative study could discern whether the particular vertical agency issues highlighted in the current work are prevalent across other franchise sectors such as hotels. It would also be valuable to understand how isomorphic pressures present themselves across other franchise sectors. Studies which explore these issues in other countries where institutional frameworks are at an early stage of development could have further theoretical 
implications. Understanding the process of how franchise industries achieve legitimacy and definition would be particularly useful.

Finally, it is clear that the addition of institutional theory provides a more holistic understanding of the franchising relationship in an emerging franchise market. This has implications for our understanding of developed markets. Therefore we would caution against assumptions that traditional economics-based franchising theory fully explains franchise activity in developed economies.

One of the major strengths of the current work is deemed to be the securing of access to both franchisors and franchisees in order to explore the franchise relationship. The complexity and difficulty of continuing work in this vein should not be underestimated by the academic community. The paper has detailed the process of accessing these franchise networks and it is hoped that this will aid researchers in their future endeavours to research franchise issues in China. 


\section{References}

Barthelemy, J. (2008), "Opportunism, knowledge and the performance of franchise chains", Strategic Management Journal, Vol. 29, pp.1451-1463.

Barthelemy, J. (2011), "Agency and institutional influences in franchising decisions", Journal of Business Venturing, Vol.26 No.1, pp.93-103.

Brickley, J.A. and Dark, F.H. (1987), "The choice of organizational form, the case of franchising", Journal of Financial Economics, Vol.18, pp.401-420.

Brookes, M. and Roper, A. (2011), "International master franchise agreements: An investigation of control from operational, relational and evolutionary perspectives", European Journal of Marketing, Vol.45 No.7/8, pp.1253-1276.

Bruton, G.D. and Ahlstrom, D. (2003), “An institutional view of China's venture capital industry: explaining the differences between China and the West", Journal of Business Venturing, Vol.18, pp.233-259.

Castrogiovanni, G.J., Combs, J.G. and Justis, R.T. (2006a), "Shifting imperatives: an integrative view of resource scarcity and agency reasons for franchising", Entrepreneurship: Theory and Practice, Vol.30 No.1, pp.23-40.

Castrogiovanni, G.J., Combs, J.G. and Justis, R.T. (2006b), "Resource scarcity and agency theory predictions concerning the continued use of franchising in multi-outlet networks", Journal of Small Business Management, Vol.44 No.1, pp.27-44.

China Daily (2011) http://usa.chinadaily.com.cn/business/2011-09/17/content 13725653.htm accessed 28 December 2011.

Combs, J., Michael, S. and Castrogiovanni, G. (2004a), "Franchising: a review and avenues to greater theoretical diversity", Journal of Management, Vol.30, pp.907-931.

Combs, J.G., Michael, S.C. and Castrogiovanni, G.J. (2009), "Institutional influences in the choice of organizational form: the case of franchising", Journal of Management, Vol. 35 No.5, pp.1268-1290.

Cope, J. (2011), "Entrepreneurial learning from failure: An interpretive phenomenological analysis", Journal of Business Venturing, Vol.26 No.6, pp.604-623.

Dant, R.P. (2008), “A futuristic research agenda for the field of franchising”, Journal of Small Business Management, Vol.46 No.1, pp.91-98.

Di Maggio, P.J. (1991), “Constructing an organizational field as a professional project: US Art Museums, 1920-40", in Powell, W.W. and DiMaggio P.J. (Eds) The New Institutionalism in Organizational Analysis, University of Chicago Press, Chicago, pp.267-292.

DiMaggio, P.D. and Powell, W.W. (1983), "The iron cage revisited: institutional isomorphism and collective rationality in organizational field", American Sociological Review, Vol.48, pp.147-160. 
Doherty, A.M. (2007), "Support mechanisms in international retail franchise networks", International Journal of Retail and Distribution Management, Vol.35 No.10, pp.781-802.

Doherty, A.M. (2009), "Market and partner selection processes in international retail franchising", Journal of Business Research, Vol. 62, pp.528-534.

Doherty, A.M. and Alexander, N. (2004) 'Relationship development in international retail franchising: Case study evidence from the UK fashion sector', European Journal of Marketing, Vol. 38 No. 9/10, pp.1215-1235.

Doherty, A.M. and Alexander, N. (2006), "Power and control in international retail franchising”, European Journal of Marketing, Vol.40 No.11/12, pp.1292-1316.

Eisenhardt, K.M. (1989), "Building theories from case study research", Academy of Management Review, Vol.14 No.4, pp.532-550.

Elango, B. and Fried, V.H. (1997), "Franchising research: a literature review and synthesis", Journal of Small Business Management, Vol.35 No.3, pp.68-81.

Franchiseek (2011) http://www.franchiseek.com/USA/Franchise USA_Statistics.htm, accessed 28 December 2012.

Frazer, L., Merrilees, B. and Wright, O. (2007), "Power and control in the franchise network: an investigation of ex-franchisees and brand piracy", Journal of Marketing Management, Vol.23 No.9-10, pp.1037-1054.

Frazer, L., Weaven, S., Giddings, J. and Grace, D. (2012), "What went wrong? Franchisors and franchisees disclose the causes of conflict in franchising", Qualitative Market Research: An International Journal, Vol.15 No.1, pp.87-103.

French, J.F. and Raven, B. (1959), "The bases of social power", in Cartwright, D. (Ed) Studies in Social Power, University of Michigan, Ann Arbor, MI.

Fulop, C. and Forward, J. (1997), "Insights into franchising: a review of empirical and theoretical perspectives", The Service Industries Journal, Vol.17 No.4, pp.603-625.

Gaski, J. (1984), "The theory of power and conflict in channels of distribution", Journal of Marketing, Vol.48, pp.9-29.

Giddens, A. (1984), The Constitution of Society: Outline of the Theory of Structuration, Polity Press, Cambridge.

Grbich, C. (2007), Analyzing qualitative data, London: Sage

Grunhagen, M. and Dorsch, M.J. (2003), "Does the franchisor provide value to franchisees? Past, current, and future value assessments of two franchisee types", Journal of Small Business Management, Vol.41 No.4, pp.366-384. 
Holmberg, S.R. and Morgan, K.B. (2003), "Franchisor turnover and failure: new research and perspective", Journal of Business Venturing, Vol.18, pp.403-418.

Jensen, M. and Meckling, W. (1976), "Theory of the firm: managerial behaviour, agency costs and ownership structure", Journal of Financial Economics, Vol.3, pp.305-360.

Kaufmann, P.J. and Stern, L.W. (1988), "Relational exchange norms, perception of unfairness, and retained hostility in commercial litigation", Journal of Conflict Resolution, Vol.32 No.3, pp.534-552.

Kedia, B.L., Ackerman, D.J., Bush, D. and Justis, R.T. (1994), "Determinants of internationalization of franchise operations by US franchisors", International Marketing Review, Vol.11 No.4, pp.56-68.

Kidwell, R.E., Nygaard, A. and Silkoset, R. (2007), “Antecedents and effects of free riding in the franchisor-franchisee relationship", Journal of Business Venturing, Vol.22, pp.522-544.

Kvale, S. and Brinkmann, S. (2009) InterViews: Learning the craft of qualitative research interviewing, London: Sage Publication

Lu, J. and Tao, Z. (2010), "Determinants of entrepreneurial activities in China", Journal of Business Venturing, Vol. 25, pp.261-273.

Lusch, R.F. (1976), "Sources of power: their impact on intrachannel conflict", Journal of Marketing Research, Vol.13, pp.382-90.

Lusch, R.F. (1982), Management of Retail Enterprises, Kent Publishing, Boston, Mass.

Mathewson, G. and Winter, R. (1985), "The economics of franchise contracts", Journal of Law and Political Economics, Vol.28, pp.503-526.

McIntyre, F. (1996), "Advertising decisions and support services: domestic versus international franchising”, Journal of Marketing Theory and Practice, Vol. 4 No.1, pp.35-42.

Meek, W.R., Davis-Sramek, B., Baucus, M., and Germain, R.N. (2011), "Commitment in franchising: the role of collaborative communication and a franchisee's propensity to leave", Entrepreneurship Theory and Practice, Vol.35 No.3, pp.559-581.

Miles, M. B. and Huberman, A. M. (1994), Qualitative data analysis: An introduction, Thousand Oaks, CA: Sage

Moore, C.M., Birtwistle, G. and Burt, S. (2004), "Channel power, conflict and conflict resolution in international fashion retailing", European Journal of Marketing, Vol.38 No.7, pp.749-769.

North, D.C. (1990), Institutions, Institutional Change and Economic Performance, Cambridge University Press: NY.

Quinn, B. (1999), "Control and support in an international franchise network", International Marketing Review, Vol.16 No.4/5, pp.345-362. 
Quinn, B. and Doherty, A.M. (2000) "Power and control in international retail franchising: Evidence from theory and practice", International Marketing Review, Vol.17 No.4/5, pp.354372.

Rahatullah, M.K. and Raeside, R. (2008), "Towards operational excellence in franchising: Achieving synergy, adding value and security competitive advantage by exploiting entrepreneurial traits and core competencies", SAM Advanced Management Journal, Summer, pp.25-38.

Research in China (2011), China Franchise Market Report 2010, China Business Intelligence, Beijing, China.

Rubin, H. (1987), "The theory of the firm and the structure of the franchise contract", Journal of Law and Economics, Vol.21, pp.223-233.

Saldaña, J. (2009), The Coding Manual for Qualitative Researchers, London: Sage.

Saldaña, J. (2013), The Coding Manual for Qualitative Researchers, London: Sage.

Scott, W.R. (1995), Institutions and Organizations: Ideas and Interests, 1st edition, Sage Publications, LA.

Scott, W.R. (2008), Institutions and Organizations: Ideas and Interests, $3^{\text {rd }}$ edition, Sage Publications, LA.

Shane, S. and Foo, M-D. (1999) "New firm survival: Institutional explanations for new franchisor mortality", Management Science, Vol.45 No.2, pp.142-159.

Spinelli, S. and Birley, S. (1996), "Towards a theory of conflict in the franchise system", Journal of Business Venturing, Vol.11, pp.329-342.

Tan, J., Yang, J. and Veliyath, R. (2009), "Particularistic and system trust among small and medium enterprises: A comparative study in China's transition economy", Journal of Business Venturing, Vol. 24, pp.544-557.

Wang, Z.J., Zhu, M. and Terry, A. (2008), "The development of franchising in China", Journal of Marketing Channels, Vol.15 No.2/3, pp.167-184.

Welsh, D.H.B., Alon, I., and Falbe, C.M. (2006) "An examination of international retail franchising in emerging markets", Journal of Small Business Management, Vol. 44 No.1, pp.130-149.

Xiao, Q., O’Neill, J.W. and Wang, H. (2008), "International hotel development: astudy of potential franchisees in China", International Journal of Hospitality Management, Vol.27, pp. 325-336. 
Table I: Key Tenets of Agency Theory and Institutional Theory

\begin{tabular}{|c|c|}
\hline Agency Theory & Institutional Theory \\
\hline $\begin{array}{l}\text { Key concepts (Jensen and Meckling, 1976) } \\
\text { - Principal-agent relationship } \\
\text { - Information asymmetry (IA)* } \\
\text { - Moral hazard } \\
\text { - Monitoring costs } \\
\text { - Contracts }\end{array}$ & $\begin{array}{l}\text { Three pillars of institutionalism form the } \\
\text { basis for legitimacy (Scott, 2008) } \\
\text { - Regulative } \\
\text { - Normative } \\
\text { - Cultural cognitive }\end{array}$ \\
\hline $\begin{array}{l}\text { - Horizontal agency problem: potential } \\
\text { for free riding }\end{array}$ & $\begin{array}{l}\text { - Regulative systems must be enforced } \\
\text { by a legitimate state } \\
\text { - Coercion key control mechanism } \\
\text { - Has much in common with agency } \\
\text { perspectives }\end{array}$ \\
\hline $\begin{array}{l}\text { - Vertical agency problem: potential for } \\
\text { employees (agents) to operate in their } \\
\text { own self-interest against the interests } \\
\text { of management (principal) }\end{array}$ & $\begin{array}{l}\text { - Normative systems involve values } \\
\text { and norms that impose constraints on } \\
\text { society } \\
\text { - The regulative and normative pillars } \\
\text { can be mutually reinforcing; (Scott, } \\
\text { 2008, p.53) }\end{array}$ \\
\hline $\begin{array}{l}\text { - Hierarchical dependent relationship } \\
\text { with coercion the key method of } \\
\text { control }\end{array}$ & $\begin{array}{l}\text { - Cultural cognitive systems involve a } \\
\text { 'taken-for grantedness', the way } \\
\text { things are done }\end{array}$ \\
\hline $\begin{array}{l}\text { - Well established application of } \\
\text { agency theory in the franchising } \\
\text { context beginning with Rubin (1978) }\end{array}$ & $\begin{array}{l}\text { Limited but growing understanding of } \\
\text { the potential of institutional theory for } \\
\text { understanding franchising (Shane and } \\
\text { Foo, 1999; Combs et al., 2009; } \\
\text { Barthelemy, 2011) }\end{array}$ \\
\hline
\end{tabular}

Note*: IA is not a problem in itself in the principal agent relationship. It becomes a problem when combined with moral hazard, that is the potential for the agent to act in his/her own interest against the interests of the principal 
Table II: Franchise Regulation Development in China

\begin{tabular}{|c|c|c|c|}
\hline Date & Law & Key Measures & Significance \\
\hline $\begin{array}{l}\text { November } \\
1997\end{array}$ & $\begin{array}{l}\text { Interim Measures } \\
\text { on the } \\
\text { Administration of } \\
\text { Commercial } \\
\text { Franchise } \\
\text { Operations (Trial } \\
\text { Implementation) }\end{array}$ & $\begin{array}{l}\text { Described how franchising worked as opposed to setting out } \\
\text { specific rules and regulation }\end{array}$ & $\begin{array}{l}\text { First official recognition of } \\
\text { franchising as a distinct business } \\
\text { model signalling official } \\
\text { encouragement to engage in } \\
\text { franchising in China } \\
\text { Only applied to domestic } \\
\text { franchisors }\end{array}$ \\
\hline $\begin{array}{l}\text { Adopted } 30 \\
\text { December } \\
2004, \text { took } \\
\text { effect } \\
1 \text { February } \\
2005\end{array}$ & $\begin{array}{l}\text { Measures for the } \\
\text { Administration of } \\
\text { Commercial } \\
\text { Franchise } \\
\text { Operations }\end{array}$ & $\begin{array}{l}\text { Requires all franchising activity to adhere to principles of } \\
\text { 'voluntariness, fair dealing, honesty and credibility' } \\
\text { Key tenets: Rights and obligations of both parties, prior disclosure } \\
\text { and content of franchise agreement covered } \\
\text { Permits a franchisor to grant either a master franchise or direct } \\
\text { franchise which allows the franchisee to sub-franchise } \\
\text { Franchise term must be at least } 3 \text { years } \\
\text { Franchisors must have at least two directly owned stores operating } \\
\text { in China for a period of at least one year in order to qualify as a } \\
\text { franchisor (2+1 rule) } \\
\text { International franchisors must apply to engage in franchising by } \\
\text { submitting a series of documentation including business license, } \\
\text { proof of qualification to be a franchisor, franchise agreement, } \\
\text { franchise manual and prior disclosure information including } \\
\text { audited financial statements, information about existing } \\
\text { franchisees, information regarding all litigation during } 5 \text { years } \\
\text { preceding a franchise agreement }\end{array}$ & $\begin{array}{l}\text { Replaced the } 1997 \text { measures and } \\
\text { implements the Regulations on } \\
\text { Foreign Investments in } \\
\text { Commercial Industry which } \\
\text { became effective on } 1 \text { June } 2004 \\
\text { Necessary due to WTO } \\
\text { accession in } 2001 \\
\text { Covers both domestic and } \\
\text { international franchisors } \\
\text { Somewhat confusing, for } \\
\text { example, the Measures fail to } \\
\text { address cross-border franchising } \\
\text { between foreign franchisors and } \\
\text { domestic Chinese franchisees } \\
\text { Confusing with regard to how } \\
\text { the } 2+1 \text { rule effects international } \\
\text { franchisors }\end{array}$ \\
\hline $\begin{array}{l}\text { Adopted } 31 \\
\text { January } \\
2007, \text { took } \\
\text { effect } 1 \\
\text { May 2007 }\end{array}$ & $\begin{array}{l}\text { Regulations on } \\
\text { the } \\
\text { Administration of } \\
\text { Commercial } \\
\text { Franchises }\end{array}$ & $\begin{array}{l}\text { Overrides any parts of the Measures that contradict the Regulation } \\
\text { Filing Rules and Disclosure Rules issued to help enforce the } \\
\text { Regulation } \\
\text { Attempts to counteract domestic franchise fraud } \\
\text { Only corporations, not individuals, can become franchisors } \\
\text { Franchisors must have a mature business that can provide } \\
\text { sufficient support to franchisees including a franchise manual, } \\
\text { training and other services. However, the Regulation is not specific } \\
\text { on exactly what support must be provided } \\
\text { Franchisors must disclose all relevant information in order that } \\
\text { franchisees make informed investment decisions when entering } \\
\text { into a franchise agreement } \\
\text { Registration must take place within } 15 \text { days of a franchisor entering } \\
\text { into a franchise agreement. } \\
\text { The franchise agreement must contain specific issues such as a } \\
\text { 'cooling-off' period and franchisees are bound to confidentiality } \\
\text { with regard to franchisors trade secrets }\end{array}$ & $\begin{array}{l}\text { Attempts to address certain } \\
\text { ambiguities, particularly with } \\
\text { regard to international franchise } \\
\text { arrangements } \\
\text { Some elements of ambiguity } \\
\text { still apply with regard to the } 2+1 \\
\text { rule but the requirement that } \\
\text { ownership must be in China has } \\
\text { been removed } \\
\text { As a result of ambiguity it } \\
\text { remains to be seen how } \\
\text { enforcement will operate }\end{array}$ \\
\hline
\end{tabular}

Source: Adapted from www.franchise-update.com/article/316, accessed 18/09/2009; www.franchisebusiness.com.au/c/DC-Strategy/China-The-New-Franchise-Frontier-n852223 accessed 18/11/2011; www.fargre.com/showarticle.aspx?Show=2981\&PrintPage=True, accessed 19/09/2009; www.asiabizblog.com/archives/2007/03/guest_column_ch.htmaccessed 18/11/2011 
Table III: The Case Companies

\begin{tabular}{|c|c|c|c|c|c|c|c|}
\hline Case & $\begin{array}{l}\text { Franchisor } \\
\text { Respondent }\end{array}$ & $\begin{array}{l}\text { Length of } \\
\text { Interview } \\
\text { (approx) }\end{array}$ & $\begin{array}{l}\text { Franchisee } \\
\text { Respondent }\end{array}$ & $\begin{array}{l}\text { Length of } \\
\text { Interview } \\
\text { (approx) }\end{array}$ & $\begin{array}{l}\text { First Year } \\
\text { Franchising } \\
\text { in China }\end{array}$ & Retail Sector & Origin \\
\hline A & $\begin{array}{l}\text { Franchisor } \\
\text { representative } \\
\text { in China }\end{array}$ & $\begin{array}{l}60 \\
\text { minutes }\end{array}$ & $\begin{array}{l}\text { Franchisee } \\
\text { owner }\end{array}$ & 45 minutes & 2003 & $\begin{array}{l}\text { Shopping } \\
\text { Goods - } \\
\text { Kitchenware }\end{array}$ & US \\
\hline B & $\begin{array}{l}\text { Franchise } \\
\text { manager }\end{array}$ & $\begin{array}{l}45 \\
\text { minutes }\end{array}$ & $\begin{array}{l}\text { Franchisee } \\
\text { owner }\end{array}$ & 50 minutes & 2000 & $\begin{array}{l}\text { Shopping } \\
\text { Goods } \\
\text { Health } \\
\text { Products }\end{array}$ & China \\
\hline $\mathrm{C}$ & $\begin{array}{l}\text { Franchise } \\
\text { manager }\end{array}$ & $\begin{array}{l}90 \\
\text { minutes }\end{array}$ & $\begin{array}{l}\text { Franchisee } \\
\text { owner }\end{array}$ & 45 minutes & 2004 & $\begin{array}{l}\text { Shopping } \\
\text { Goods } \\
\text { Health } \\
\text { Products }\end{array}$ & China \\
\hline $\mathrm{D}$ & $\mathrm{CEO}$ & $\begin{array}{l}60 \\
\text { minutes }\end{array}$ & $\begin{array}{l}\text { Franchisee } \\
\text { owner }\end{array}$ & 50 minutes & 2004 & $\begin{array}{l}\text { Convenience } \\
\text { stores }\end{array}$ & China \\
\hline $\mathrm{E}$ & $\begin{array}{l}\text { Franchise } \\
\text { manager }\end{array}$ & $\begin{array}{l}45 \\
\text { minutes }\end{array}$ & $\begin{array}{l}\text { Franchisee } \\
\text { owner }\end{array}$ & 45 minutes & 2004 & $\begin{array}{l}\text { Convenience } \\
\text { stores }\end{array}$ & China \\
\hline $\mathrm{F}$ & $\begin{array}{l}\text { Franchise } \\
\text { manager }\end{array}$ & $\begin{array}{l}60 \\
\text { minutes }\end{array}$ & $\begin{array}{l}\text { Franchisee } \\
\text { owner }\end{array}$ & 45 minutes & 2004 & $\begin{array}{l}\text { Convenience } \\
\text { stores }\end{array}$ & China \\
\hline G & $\mathrm{CEO}$ & $\begin{array}{l}50 \\
\text { minutes }\end{array}$ & $\begin{array}{l}\text { Franchisee } \\
\text { owner }\end{array}$ & 45 minutes & 2004 & $\begin{array}{l}\text { Convenience } \\
\text { stores }\end{array}$ & China \\
\hline $\mathrm{H}$ & $\begin{array}{l}\text { Franchise } \\
\text { manager }\end{array}$ & $\begin{array}{l}120 \\
\text { minutes }\end{array}$ & $\begin{array}{l}\text { CEO (master } \\
\text { franchisee) }\end{array}$ & 75 minutes & 2006 & $\begin{array}{l}\text { Convenience } \\
\text { stores }\end{array}$ & $\begin{array}{l}\text { China/ } \\
\text { Hong } \\
\text { Kong }\end{array}$ \\
\hline I & $\begin{array}{l}\text { Franchise } \\
\text { manager }\end{array}$ & $\begin{array}{l}75 \\
\text { minutes }\end{array}$ & $\begin{array}{l}\text { Franchisee } \\
\text { owner }\end{array}$ & 60 minutes & 1998 & $\begin{array}{l}\text { Convenience } \\
\text { stores }\end{array}$ & China \\
\hline
\end{tabular}


Table IV: Interview Guide: Thematic Issues and Within Theme Issues Explored in Franchisor and Franchisee Interviews

\begin{tabular}{|c|c|}
\hline Thematic Issues & Within theme issues to explore \\
\hline \multirow[t]{3}{*}{ Company franchise history } & $\begin{array}{l}\text { Year of start up, how many people are employed, } \\
\text { company size }\end{array}$ \\
\hline & $\begin{array}{l}\text { Industry and competitive environment at the point of } \\
\text { entry into franchising and how it has evolved }\end{array}$ \\
\hline & Why and how the franchise business started \\
\hline \multirow[t]{2}{*}{ Establishing franchise relationships } & $\begin{array}{l}\text { How franchise partner(s) are selected and the criteria } \\
\text { (if any) which are employed to choose partner(s) }\end{array}$ \\
\hline & How the franchise relationship was established \\
\hline \multirow[t]{4}{*}{ Day-to-day operation of the franchise business } & Structure of the franchise operation \\
\hline & $\begin{array}{l}\text { Rules, regulations and terms and conditions of the } \\
\text { franchise contracts }\end{array}$ \\
\hline & How the franchisee/franchisor operates the business \\
\hline & $\begin{array}{l}\text { How the franchisor/franchisee perceives the state of } \\
\text { the franchise operations }\end{array}$ \\
\hline+ & \\
\hline \multirow[t]{4}{*}{ Support } & $\begin{array}{l}\text { How support operates and the main methods of } \\
\text { support }\end{array}$ \\
\hline & The context for support implementation \\
\hline & $\begin{array}{l}\text { How the franchisor/franchisee perceives the support } \\
\text { given by/received from the counterpart and why it is } \\
\text { perceived this way }\end{array}$ \\
\hline & $\begin{array}{l}\text { The importance of support for the franchise } \\
\text { relationship }\end{array}$ \\
\hline \multirow[t]{4}{*}{ Control } & $\begin{array}{l}\text { How control is maintained/exerted and the main } \\
\text { methods of control in the relationship }\end{array}$ \\
\hline & The context for control implementation \\
\hline & $\begin{array}{l}\text { How the franchisor/franchisee perceives control in the } \\
\text { relationship and why it is perceived this way }\end{array}$ \\
\hline & How control impacts on the franchise relationship \\
\hline \multirow[t]{5}{*}{ Conflict } & Indicators of conflict \\
\hline & Antecedents of conflict \\
\hline & Resolutions to conflict \\
\hline & $\begin{array}{l}\text { How the franchisor/franchisee perceives conflict in the } \\
\text { relationship and why it is perceived this way }\end{array}$ \\
\hline & How conflict impacts on the franchise relationship \\
\hline \multirow[t]{4}{*}{ Power } & Sources of franchisor/franchisee power \\
\hline & How power is exercised \\
\hline & $\begin{array}{l}\text { How the franchisor/franchisee perceives power in the } \\
\text { relationship and why it is perceived this way }\end{array}$ \\
\hline & How power impacts on the franchise relationship \\
\hline
\end{tabular}


Table V: Sources of Power, Control, Support and Conflict in Retail Franchise Relationships in China

\begin{tabular}{|c|c|c|}
\hline & Franchisor & Franchisee \\
\hline Power and Control & $\begin{array}{l}\text { - Contract } \\
\text { - Brand } \\
\text { - Market information } \\
\text { - Support services } \\
\text { - System infrastructure }\end{array}$ & $\begin{array}{ll}\text { - } & \text { Store location } \\
\text { - } & \text { Market information } \\
& \text { e.g. alternative } \\
& \text { sourcing channels } \\
\text { - } & \text { Information exchange } \\
& \text { between franchisees }\end{array}$ \\
\hline Support Services & 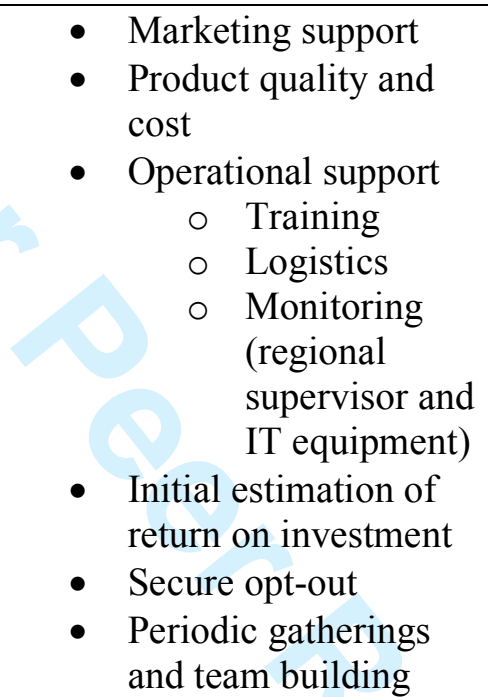 & \\
\hline Sources of Conflict & $\begin{array}{l}\text { - } \begin{array}{l}\text { Lack of competitive } \\
\text { pricing }\end{array} \\
\text { - Poor logistics and } \\
\text { transportation } \\
\text { infrastructure } \\
\text { - Franchisee } \\
\text { perceptions that } \\
\text { franchisor not } \\
\text { sufficiently effective } \\
\text { against the presence } \\
\text { of counterfeit goods } \\
\text { in market }\end{array}$ & $\begin{array}{l}\text { Purchasing products } \\
\text { from unauthorised } \\
\text { channels } \\
\text { - } \\
\text { frperienced } \\
\text { franchisees with local } \\
\text { market knowledge } \\
\text { acting against } \\
\text { franchisor } \\
\text { recommendations } \\
\text { Lack of willingness } \\
\text { to bear costs of } \\
\text { improving systems }\end{array}$ \\
\hline
\end{tabular}

